\title{
Domain structure of volcanics' ferromagnetic grains: A case study of the Saatly ultradeep well, Azerbaijan
}

\section{Z.A. Novruzov, 2019}

Institute of Geology and Geophysics of NAS of Azerbaijan, Baku, Azerbaijan

Received 21 November 2018

\begin{abstract}
Магнітні властивості різних магнітних мінералів дуже залежать від розміру зерен (доменного стану). Гірські породи часто містять суміш різних магнітних мінералів з різними розмірами зерен (доменних станів). Як матеріал для визначення доменного стану зерен мінералів використано вулканіти з надглибокої свердловини Саатлі в інтервалі глибин 3540-8126 м. За даними петрографічного та електронномікроскопічного аналізів у верхній частині розрізу (3540-5500 м) цих порід зерна рудних мінералів представлені двома генераціями: 1) великі зерна титаномагнетиту (біАні на титан), гомогенні або зі структурами розпаду; 2) невеликі за розміром, зазвичай добре ограновані зерна практично стехіометричного магнетиту. Гомогенні невеликі зерна або фрагменти розпаду великих зерен (які дуже змінені хімічно) можуть мати властивості однодоменних частинок; феромагнітні зерна часто визначають як псевдоодиничний домен. У нижній частині розрізу (5500-8126 м) мультидоменні зерна титаномагнетиту збіАнені титаном. 3 глибин 7000 м спостерігається також окиснений магнетит. Псевдооднодоменних зерен зафіксовано значно менше, ніж у верхній частині розрізу. З глибини 7300 м і нижче вони повністю відсутні. За результатами досліджень, феромагнетик представлений істотно мультидоменними зернами. Сліл зазначити, що критерій Лорі-Фуллера непридатний при ілентифікащії доменної структури складного сполучення феромагнітних зерен.
\end{abstract}

Ключові слова: непрямі магнітні критерії, магнітний доменний стан, вулканогенні породи, налглибока свердмовина.

Introduction. For the first time magnetometric researches of volcanogenic rock core of the super deep Saatly well have been conducted by the staff of department "Geomagnetism" of the Institute of Geology and Geophysics of Azerbaijan National Academy of Science (ANAS). The necessity in the magnetic researches of a core of the Saatly super deep well has been dictated by need in obtaining the petromagnetic data used at interpretations of results of geophysical activity. The ore minerals' magnetic research together with microprobe analysis of them [Novruzov, Tselmovich, 2018] revealed that magnetic properties of rocks are bound with magnetite and Ti-poor titanomagnetite.
Environmental conditions of generation of ferromagnetic minerals and changes of them leave traces on magnetic domain structure [Stackey, Banerjee, 1974]. Application of the rock magnetic method for identification of domain structure of magnetic grains is the purpose of the proposed article. For realization of this purpose we used four magnetic criteria. The criteria are based on characteristics of various magnetic parameters of magnetic grains with different magnetic domain structures.

Description of the object. The superdeep well is located near the city of Saatly $(\lambda=$ $=39.91^{\circ} \mathrm{N}, \varphi=48.36^{\circ} \mathrm{E}$ ), Azerbaijan (Fig. 1). The region of the well location (design depth 


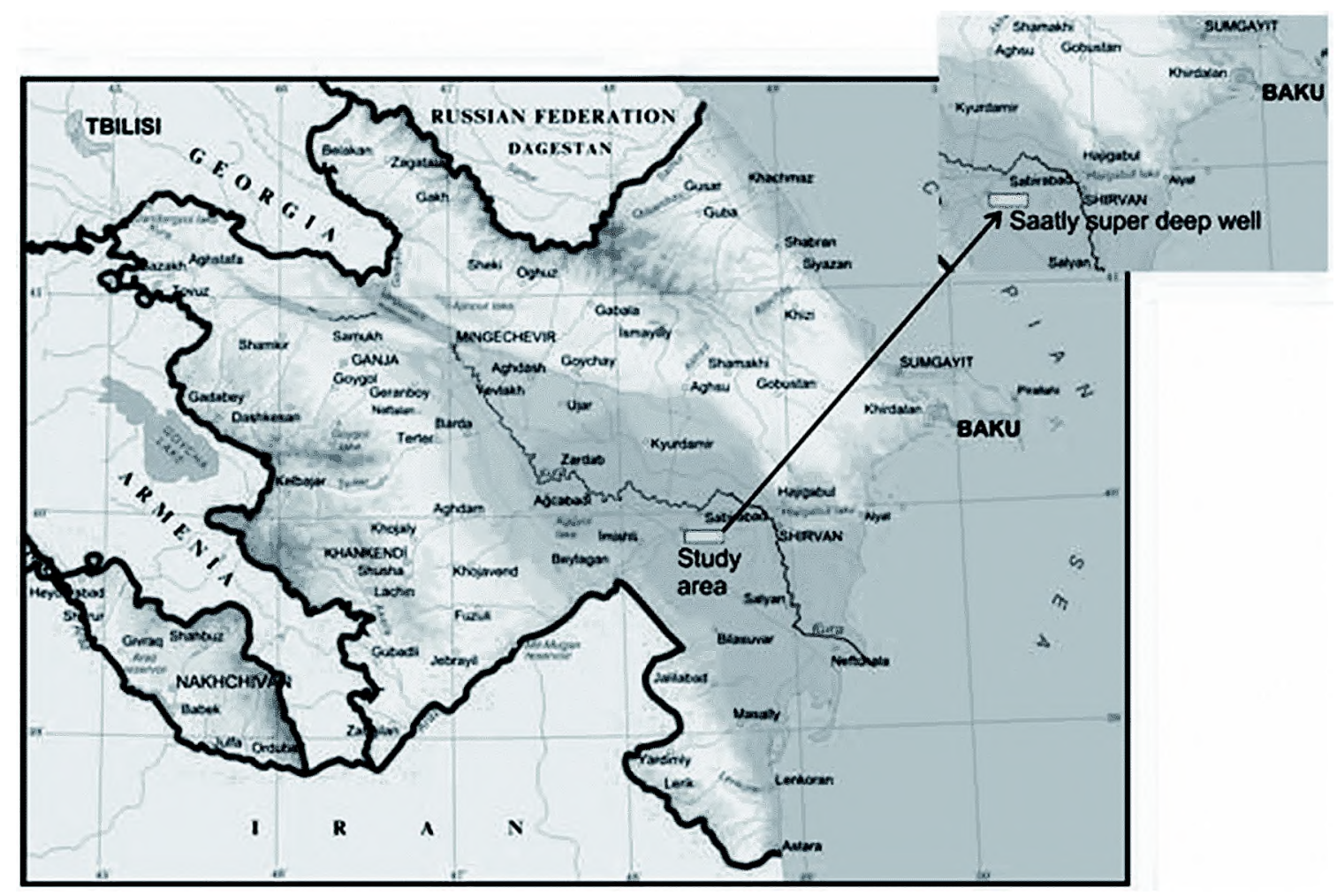

Fig. 1. The Saatly super deep well location.

of $15 \mathrm{~km}$ ) is spaced in the Kur basin placed between the Greater Caucasus and the Lesser Caucasus (the large tectonic constructions). According to deep structure the Kur basin is subdivided into three depressions: upper Kura basin, middle Kura basin and lower Kura basin. The Saatly superdeep well is located within the middle Kura basin.

According to geophysical data interpretation the crystalline basement (around the Saatly local gravitational maximum) possesses a block structure (where there are rocks of persilicic and basic composition at a depth of $8 \mathrm{~km}$ ). Debatable idea of crustal structure within the Saatly local gravitational maximum was formed in two points of view. According to the first - the Earth crust consists of granite and basalt layers, according to the second - the Earth crust is singlelayer and it is presented by mafic rocks only. Features of the Earth crust and the reduced thickness of a sedimentary cover at Saatly territory formed a basis for drilling of the super deep well.
Object of our researches are the volcanics located in the depths interval of 3540$8126 \mathrm{~m}$. According to research papers [Abdullaev, Salakhov, 1983; Abdullaev et al., 1984] the development of the low-temperature metamorphism (depth of $3540-7000 \mathrm{~m}$ ) has been noted in the volcanogenic rocks. But from depths of $7000 \mathrm{~m}$ and deeper the development of the low-temperature metasomatism is revealed. The quantities of the studied volcanic rocks were 49 . Three duplicate with cubic form $(1 \mathrm{~cm})$ were sawn from each sample.

The depth interval of $3540-3900 \mathrm{~m}$ is characterized by plagioclase basalts and is mainly presented by volcanogenic facies. Basalts contain the potassium-enriched and sodium-enriched alkalinity.

The depth interval of $3900-4850 \mathrm{~m}$ contains porphyritic olivine-pyroxene-plagioclase-basalts and pyroxene-plagioclase-basalts. Basalts are low-alkaline (low-potassium).

The depth interval of $4850-5209$ m possesses much bigger phases of rocks. Except 
basalts their amfibole-contaning phases and andesites are noted. Along with low-potassium basalts potassium-enriched groups have been discovered.

In the depth interval of $5209-6100 \mathrm{~m}$ the double-pyroxene-plagioclase basalts and andesite-basalts prevail. These rocks possess the alkalescence and the strong fracturing.

There are andesites in the depth interval of $6100-6800 \mathrm{~m}$. The microdolerite sills are noted as well.

Upper parts of $6800-8000 \mathrm{~m}$ depth interval are presented by dacites, dacite-tuffs and pumiceous breccia. In the middle horizons and lower ones of the interval dacites are alternating with plagiorhyolite and andesites.

Thus, the studied columnvolcanics change with depth: from the mafics (andesite-basalts, basalts) to intermediate rocks (andesites) and then to persilicrocks (rhyodacites, dacites).

Technique of works. During the magnetic researches of volcanogenic rocks of the superdeep Saatly well the following magnetic parameters were measured: a natural remanent magnetization (NRM) and magnetic susceptibility $(\chi)$. At the laboratory on each duplicate sample (for each one the NRM and the $\chi$ were measured) saturation isothermal remanent magnetization (SIRM) and isothermal remanent magnetization (IRM) in the field of $1.5 \mathrm{~T}$ have been created. At the laboratory a thermal remanent magnetization (TRM) was created on each duplicate of sample by means of cooling from temperatures above the Curie point (more than 600 ${ }^{\circ} \mathrm{C}$ ) in the presence of magnetic field equal to $0.5 \cdot 10^{-4} \mathrm{~T}$. Partial thermal remanent magnetizations (PTRM) were created from temperatures $200-500^{\circ} \mathrm{C}$ (mainly from $200^{\circ} \mathrm{C}$ ) to $20^{\circ} \mathrm{C}$ in the field of $0.5 \cdot 10^{-4} \mathrm{~T}$.

Saturation isothermal remanent magnetization (SIRM), isothermal remanent magnetization (IRS) and the thermoremanent magnetization (TRM) were measured at the laboratory.

All laboratory measurements were carried out at the laboratory of "The main geomagnetic field and a petromagnetizm" of the Institute of Physics of Solid Earth of RAS.
Natural remanent magnetization (NRM) and thermal remanent magnetization (TRM) were measured on a magnetometer JR-4 (Brno, Czech Republic). SIRM ( $M_{r s}$ ) was measured on an automatic thermomagnetometer with sensitivity $1 \cdot 10^{-4} \mathrm{~A} / \mathrm{m}$. A saturation magnetization $\left(M_{s}\right)$ was measured on a vibromagnetometer with sensitivity $1 \cdot 10^{-1} \mathrm{~A} / \mathrm{m}$. The magnetic susceptibility was measured on a Kappabridge KLY-2 (Brno, Czech Republic).

Stepwise demagnetization by increasing alternating field was carried out on the RUV semi-automatic installation in the range of fields of $0-80 \mathrm{~A} / \mathrm{m}$. The PTRM were thermally demagnetized by a routine technique [Kobayashi, Fuller, 1967].

Results of the researches. Magnetic researches of the well volcanogenic rocks showed that the measured magnetic parameters of $M_{r s}$ and $M_{s}$ and TRM and $Q_{n}$ are changing according to depth. Changes of these parameters reflect variations of grain size. Magnetic parameters of NRM, $\chi$, SIRM $\left(M_{r s}\right), M_{s}$ and TRM were measured for study of a minerals' magnetic domain state of the Saatly superdeep well. There are three types of different magnetic behavior, depending on the grain size. The defined parameters allowed calculating $Q_{n}$ factor and magnitude of $M_{r s} / M_{s}$.

For use of magnetothermal criterion the partial thermal remanent magnetizations (PTRM) were created. The PTRM were acquired in the range of temperatures $200-500{ }^{\circ} \mathrm{C}$. For identification of a magnetic domain state of volcanic ferromagnetic grains of the Saatly well the four magnetic criteria were used: factor $Q_{n}, M_{r s} / M_{s}$, Lauri-Fuller's criterion and thermal magnetic criterion.

Short consideration of identification criteria of a magnetic domain state had brought to light that that any of criteria does not work completely well, even in case of ensembles of "pure" grains. The found structural heterogeneities of grains [Novruzov, Tselmovich, 2018] and also grains various by structure and the sizes (magnetic researches of the structure and concentration) make impossible to use only one of the mentioned criteria. Therefore in this article, the 
most often used in rock magnetism the four criteria are applied. At the same time the judgment of a magnetic domain state was based on coincidence of results of identification by the two or the three criteria.
The results of identification of a magnetic domain state of the ferromagnetic grains are presented in Table. In Fig. 2 and Fig. 3 typical demagnetization curves of TRM and SIRM in alternating magnetic field (Lauri-

The experimental results of definition of a magnetic domain structure of ferromagnetic grains of volcanogenic rocks of the Saatly well section (interval of $3540-8126 \mathrm{~m}$ )

\begin{tabular}{|c|c|c|c|c|c|c|c|c|}
\hline \multirow[b]{2}{*}{$\begin{array}{l}\text { Type } \\
\text { of rock }\end{array}$} & \multirow[b]{2}{*}{ Depts, m } & \multicolumn{7}{|c|}{ Criterion } \\
\hline & & $Q_{n}$ & $\begin{array}{c}\text { Domain } \\
\text { state }\end{array}$ & $M_{r s} / M_{S}$ & $\begin{array}{c}\text { Domain } \\
\text { state }\end{array}$ & $\begin{array}{c}\text { Lauri- } \\
\text { Fuller }\end{array}$ & $\begin{array}{c}\text { Thermo- } \\
\text { mag- } \\
\text { netic }\end{array}$ & Total \\
\hline $\begin{array}{c}\text { Andesite- } \\
\text { basalt }\end{array}$ & $3540-3546$ & 0,15 & MD & 0,04 & $\mathrm{SD}$ & - & MD & MD \\
\hline Basalt & $3660-3666$ & 2,03 & PSD & 0,26 & $\mathrm{SD}$ (PSD) & - & $\mathrm{MD}$ & MD (PSD) \\
\hline Basalt & $3761-3767$ & 0,29 & $\mathrm{MD}$ & 0,17 & PSD & SD & $\mathrm{MD}$ & MD \\
\hline Basalt & $3820-3825$ & 0,51 & $\mathrm{MD}$ & 0,13 & PSD & SD & - & MD (PSD) \\
\hline Basalt & $3975-3981$ & 1,71 & PSD & 0,13 & PSD & $\mathrm{SD}$ & - & PSD \\
\hline Basalt & $4062-4067$ & 0,33 & $\mathrm{MD}$ & 0,10 & PSD & $?$ & - & MD (PSD) \\
\hline Basalt & $4165-4171$ & 2,55 & PSD & 0,24 & PSD & $\mathrm{SD}$ & $\mathrm{MD}$ & PSD \\
\hline Basalt & $4250-4255$ & 0,41 & $\mathrm{MD}$ & 0,12 & PSD & $\mathrm{SD}$ & $\mathrm{MD}$ & MD (PSD) \\
\hline Basalt & $4310-4315$ & 0,18 & $\mathrm{MD}$ & 0,04 & $\mathrm{MD}$ & $\mathrm{SD}$ & $\mathrm{MD}$ & MD \\
\hline $\begin{array}{c}\text { Andesite- } \\
\text { basalt }\end{array}$ & $4423-4428$ & 0,31 & $\mathrm{MD}$ & 0,07 & $\mathrm{MD}$ (PSD) & $\mathrm{SD}$ & - & MD \\
\hline Basalt & $4516-4522$ & 0,83 & $\mathrm{MD}$ & 0,06 & $\mathrm{MD}$ (PSD) & $\mathrm{SD}$ & - & MD \\
\hline Basalt & $4600-4608$ & 1,30 & PSD & 0,03 & $\mathrm{MD}$ & $\mathrm{SD}$ & $\mathrm{MD}$ & MD (PSD) \\
\hline Basalt & $4634-4640$ & 0,68 & $\mathrm{MD}$ & 0,07 & $\mathrm{MD}$ (PSD) & $\mathrm{SD}$ & $\mathrm{MD}$ & MD \\
\hline Basalt & $4686-4692$ & 0,74 & $\mathrm{MD}$ & 0,08 & $\mathrm{MD}(\mathrm{PSD})$ & $\mathrm{SD}$ & $\mathrm{MD}$ & MD \\
\hline Dolerite & $4714-4719$ & 0,32 & $\mathrm{MD}$ & 0,07 & $\mathrm{MD}$ (PSD) & $\mathrm{SD}$ & - & MD \\
\hline Dolerite & $4770-4777$ & 0,81 & $\mathrm{MD}$ & 0,05 & $\mathrm{MD}$ & $\mathrm{SD}$ & $\mathrm{MD}$ & MD \\
\hline $\begin{array}{c}\text { Andesite- } \\
\text { basalt }\end{array}$ & $4800-4807$ & 1,82 & PSD & 0,04 & $\mathrm{MD}$ & $\mathrm{MD}$ & - & MD \\
\hline $\begin{array}{c}\text { Andesite- } \\
\text { basalt }\end{array}$ & $4881-4885$ & 0,60 & MD & 0,02 & MD & SD & - & MD \\
\hline Basalt & $4915-4922$ & 1,39 & PSD & 0,02 & $\mathrm{MD}$ & $\mathrm{SD}$ & $\mathrm{MD}$ & MD (PSD) \\
\hline Andesine & $5036-5040$ & 0,30 & MD & 0,04 & $\mathrm{MD}$ & SD & MD & MD \\
\hline $\begin{array}{c}\text { Gabbros- } \\
\text { norite }\end{array}$ & $5129-5132$ & 0,35 & MD & 0,06 & MD (PSD) & SD & MD & MD \\
\hline Basalt & $5185-5190$ & 0,69 & $\mathrm{MD}$ & 0,03 & $\mathrm{MD}$ & $\mathrm{SD}$ & $\mathrm{MD}$ & MD \\
\hline Basalt & $5270-5273$ & 3,00 & PSD & 0,06 & $\mathrm{MD}$ (PSD) & $\mathrm{SD}$ & $\mathrm{MD}$ & MD (PSD) \\
\hline Basalt & $5385-5390$ & 1,40 & PSD & 0,04 & $\mathrm{MD}$ & $\mathrm{SD}$ & - & MD (PSD) \\
\hline
\end{tabular}


Fuller's criterion) are represented. In Fig. 4 ses grains of magnetic minerals (carriers of typical thermal demagnetization curves of remanent magnetization), are in a multidoPTRM acquired at different temperatures (ther- main state. For an upper part of a section mal magnetic criterion) are presented. of volcanogenic rocks $(3540-5500 \mathrm{~m})$, espe-

We can see in the table that in most ca- cially in the depth interval of $3540-5000 \mathrm{~m}$,

Continuation of Table

\begin{tabular}{|c|c|c|c|c|c|c|c|c|}
\hline Basalt & $5467-5474$ & 0,53 & MD & 0,05 & MD & SD & - & MD \\
\hline Andesite & $5544-5550$ & 1,89 & PSD & 0,07 & MD (PSD) & SD & MD & MD (PSD) \\
\hline Basalt & $5634-5636$ & 5,95 & PSD & 0,08 & $\mathrm{MD}$ (PSD) & $\mathrm{SD}$ & $\mathrm{MD}$ & MD (PSD) \\
\hline $\begin{array}{c}\text { Andesite- } \\
\text { basalt }\end{array}$ & $5746-5750$ & 2,12 & PSD & 0,11 & PSD & $\mathrm{SD}$ & $\mathrm{MD}$ & PSD \\
\hline Andesite & $5828-5830$ & 5,48 & PSD & 0,08 & MD (PSD) & SD & MD & MD (PSD) \\
\hline Andesite & $6000-6003$ & 1,36 & PSD & 0,07 & $\mathrm{MD}$ (PSD) & $\mathrm{SD}$ & - & MD (PSD) \\
\hline Andesite & $6174-6178$ & 0,68 & $\mathrm{MD}$ & 0,03 & $\mathrm{MD}$ & $?$ & - & MD \\
\hline $\begin{array}{c}\text { Andesite- } \\
\text { basalt }\end{array}$ & $6290-6295$ & 1,00 & MD & 0,05 & MD & $?$ & - & MD \\
\hline Andesite & $6430-6435$ & 1,00 & $\mathrm{MD}$ (PSD) & 0,07 & $\mathrm{MD}$ (PSD) & $\mathrm{SD}$ & - & MD (PSD) \\
\hline Andesite & $6581-6583$ & 1,72 & PSD & 0,08 & $\mathrm{MD}$ (PSD) & $\mathrm{SD}$ & MD0 & MD (PSD) \\
\hline $\begin{array}{c}\text { Andesite- } \\
\text { basalt }\end{array}$ & $6740-6745$ & 2,90 & PSD & 0,03 & $\mathrm{MD}$ & $\mathrm{SD}$ & - & MD (PSD) \\
\hline Andesite & $6877-6882$ & 1,15 & $\begin{array}{c}\mathrm{MD} \\
\text { (PSD) }\end{array}$ & 0,06 & $\mathrm{MD}$ (PSD) & SD & - & MD (PSD) \\
\hline Dolerite & $6994-7003$ & 1,87 & PSD & 0,13 & PSD & SD & $\mathrm{MD}$ & MD (PSD) \\
\hline Dacite & $7038-7048$ & 0,50 & MD & 0,07 & MD (PSD) & MD & - & MD \\
\hline Dacite & $7172-7176$ & 2,15 & PSD & 0,05 & MD (PSD) & SD & - & MD (PSD) \\
\hline Rhyodacite & $7264-7276$ & 0,29 & $\mathrm{MD}$ & 0,31 & $\mathrm{SD}$ (PSD) & SD & - & MD (PSD) \\
\hline Dolerite & $7332-7343$ & 0,49 & $\mathrm{MD}$ & 0,03 & $\mathrm{MD}$ & $\mathrm{SD}$ & - & MD \\
\hline Rhyodacite & $7420-7428$ & 0,50 & MD & 0,04 & MD & SD & MD & MD \\
\hline Dacite & $7576-7578$ & 0,85 & $\mathrm{MD}$ & 0,06 & $\mathrm{MD}$ (PSD) & $\mathrm{SD}$ & $\mathrm{MD}$ & MD \\
\hline Dacite & $7642-7646$ & 0,25 & $\mathrm{MD}$ & 0,04 & $\mathrm{MD}$ & $?$ & - & MD \\
\hline Dacite & $7729-7738$ & 1,77 & PSD & 0,05 & $\mathrm{MD}$ (PSD) & $\mathrm{SD}$ & $\mathrm{MD}$ & MD \\
\hline Rhyodacite & $7874-7878$ & 0,21 & MD & 0,02 & MD & SD & MD & MD \\
\hline $\begin{array}{l}\text { Andesite- } \\
\text { dacite }\end{array}$ & $7991-7993$ & 0,65 & $\mathrm{MD}$ & 0,04 & $\mathrm{MD}$ & SD & $\mathrm{MD}$ & MD \\
\hline Rhyolite & $8103-8108$ & 0,57 & $\mathrm{MD}$ & 0,03 & $\mathrm{MD}$ & $\mathrm{SD}$ & $\mathrm{MD}$ & MD \\
\hline Dacite & $8108-8126$ & 0,80 & $\mathrm{MD}$ & 0,05 & $\mathrm{MD}$ & $\mathrm{SD}$ & - & MD \\
\hline
\end{tabular}

$\mathrm{SD}$ - single-domain particles; PSD — pseudo-single-domain particles; MD - multi-domain particles. 


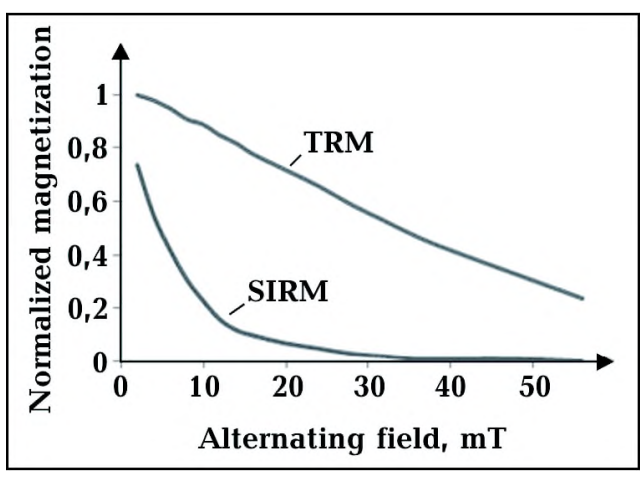

Fig. 2. The alternating magnetic field demagnetization curves (TRM and SIRM) as Lauri-Fuller's criterion for upper part of section.

the pseudo-single-domain state often becomes apparent. It demonstrates that remanent magnetization carriers in this interval of depths are the finest grains. These grains, most probably, belong, to the second generation of grains of magnetite and the Ti-poor titanomagnetite determined on the basis of microprobe analysis [Novruzov, Tselmovich, 2018].

In the bottom of a section (5500-8126 m) is more often, and in the depth interval 7300$8126 \mathrm{~m}$ one and all studied rocks contain only multidomain grains of ferromagnetic minerals.

This result presumably can be bound to that circumstance that the low-temperature metamorphism, especially metasomatism, results in partial or complete collapse (repla-

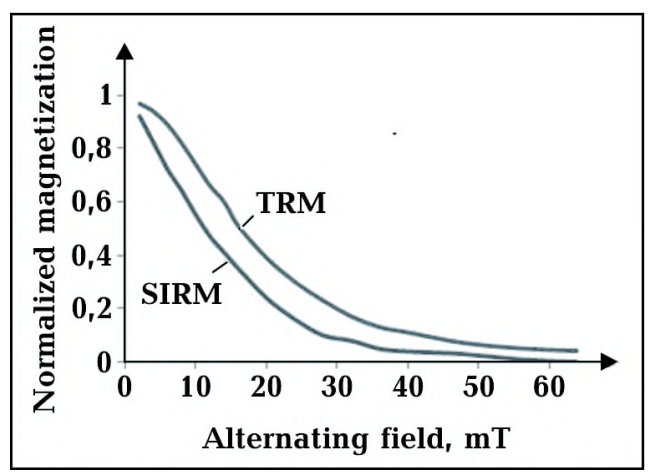

Fig. 3. The alternating magnetic field demagnetization curves (TRM and SIRM) as Lauri-Fuller's criterion for bottom part of section. cement) of fine grains of the ferromagnetic minerals in the bottom of a section which are contained in rocks.

At the same time artificial "enrichment" of rocks with more coarse magnetic grains is observed. As shown by means of microprobe [Novruzov, Tselmovich, 2018] of ore grains the fine fraction of the deepest rocks is presented, mainly, by fragments of the crushed large grains.

Discussion of results. The done petromagnetic researches showed that in most cases grains of magnetic minerals (carriers of remanent magnetization) represent an ensemble of multidomain particles. In upper part of the section (3540-5500), especially in the depth interval $3540-5000 \mathrm{~m}$, the pseudo-single domain state is often presented. It demonstrates that in this depth interval, except of course (large volume) multidomain grain generation, fine grains of other generation can bear a remanent magnetization.

The results of identification of a domain structure presented in the summary table, in the deeper section $(5500-8126 \mathrm{~m})$ are more often, and in the depth interval 7300$8126 \mathrm{~m}$ one and all ferromagnetic minerals are demonstrating only multidomain grains content. This result presumably can be caused by the fact that in the deeper section the generation (rather) of fine ferromagnetic grains can be partially or entirely destroyed due to occurrence of the low-temperature metamorphism (metasomatism). As a re-

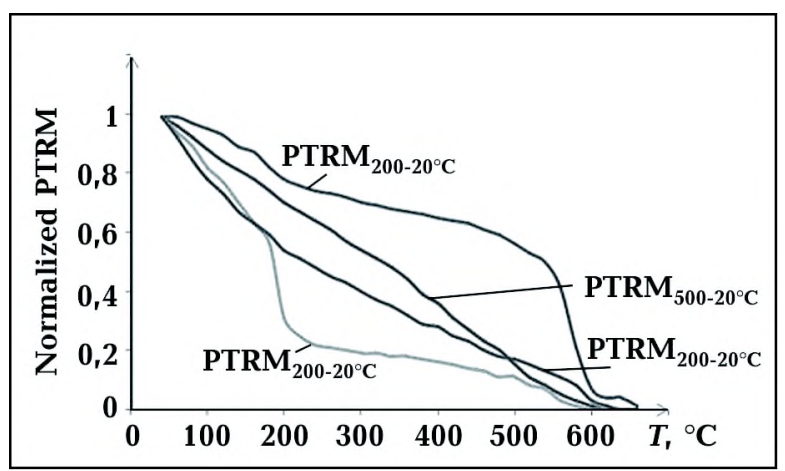

Fig. 4. Thermal demagnetization of the PTRM as thermomagnetic criterion of identification of type of domain state. 
sult the share of the ferrimagnetic coarse grains possessing a multidomain structure increases.

As is obvious from the table the LauriFuller's criterion is inapplicable for the complex ensemble of ferromagnetic grains. Use of this criterion eventuates in the diametri- cally opposite data received on the basis of the two or the three other criteria of domain structure identificationThe thermal magnetic criterion is sensitive to manifestation of single-domain (pseudo-single-domain) and of multidomain ferromagnetic grains of in the complex ensemble of grains.

\title{
Domain structure of volcanics' ferromagnetic grains: A case study of the Saatly ultradeep well, Azerbaijan
}

\author{
Z.A. Noviuzov, 2019
}

\begin{abstract}
Various magnetic properties of magnetic minerals show strong grain-size dependence. This dependency occurs because these parameters are influenced by the magnetic grain-size (domain state) of the samples. Natural rocks often contain a mixture of different magnetic minerals with different grain-size (domain states). Thus determination of the domain state is important. The Saatly ultradeep well's volcanics were used as a research material. In the depth intervals of $3540-8126 \mathrm{~m}$ the volcanics had been revealed by the borehole. According to data of the petrographic and microprobe analysis the volcanogenics of the ultradeep borehole is conditionally divided into a two parts: 1) the upper part (an interval of depths of $3540-5500 \mathrm{~m}$ ); 2) the bottom part (an interval of depths of $5500-8126 \mathrm{~m}$ ). In the upper part of section according to microprobe analysis of volcanogenic rocks ore grains are presented by two generations: 1) large grain of titanomagnetites (Ti-poor), homogeneous or with a decay structures; 2) small-sized usually well faced grain of practically stoichiometric magnetite. So, homogeneous small-sized grains or fragments of decay large grains (which are strongly changed chemically) can have properties of single-domain particles. Here the ferromagnetic grains (especially in the depth interval $3540-5000 \mathrm{~m}$ ) are often noted as a pseudo-single domain. In the bottom part of the section the presence of multidomain grains of the Ti-poor titanomagnetite is noted. And since depths of $7000 \mathrm{~m}$ the oxidized magnetite is also observed. The pseudo-single-domain grains are fixed much less than in the upper section. And, since a depth mark of $7300 \mathrm{~m}$ and deeper, they are absent wholly. In the result of research it turned out that the ferromagnetic is presented by basically multidomain grains. It should be noted that Lauri-Fuller's Criterion is not applicable at identification of a domain structure of the complex ensemble of the ferromagnetic grains.
\end{abstract}

Key words: indirect magnetic criteria, magnetic domain state, volcanogenic rocks, super deep well.

\section{References}

Abdullaev, R. N., \& Salakhov, A.S. (1983). Comparative characteristics of Jurassic volcanics Kurdamir-Saatli buried uplift and the northeastern part of the Lesser Caucasus. Izvestiya AN AzSSR, ser. Nauka o Zemle, (4), 14-23 (in Russian).

Abdullaev, R. N., Salayeva, F.O., \& Salakhov, A.S.
(1984). Magmatic complexes of the Middle Kurin depression. In Questions of mineralogy and lithology (pp. 85-90). Baku (in Russian).

Kobayashi, K., \& Fuller, M.D. (1967). Vibration magnetometer. In D. W. Collinson, K. M. Creer, \& S. K. Runcorn (Eds.), Methods in palaeo- 
magnetism (pp. 450-456). Amsterdam-London-New York: Elsevier.

Novruzov, Z.A., \& Tselmovich, V.A. (2018). Microroentgen spectral ore mineral analysis of Saatly column well volcanic (depth interval 3540$8126 \mathrm{~m})$. Stratigraphy and sedimentology of oil-gas basins (International scientific journal), (2), 70-84.

Stackey, F.D., \& Banerjee, S. K. (1974). The physical principles of rock magnetism. Amsterdam: Elsevier, 195 p. 